\title{
Understanding Slow Growth in the Adoption of E-Textbooks: Distinguishing Paper and Electronic Delivery of Course Content
}

\author{
Andrew Paul Feldstein (Corresponding author) \\ Reginald F. Lewis College of Business \\ Virginia State University, United States \\ E-mail: afeldstein@vsu.edu \\ Mirta Maruri Martin \\ Reginald F. Lewis College of Business \\ Virginia State University, United States \\ E-mail: mmartin@vsu.edu
}

Received: July 31, 2013 Accepted: August 31, 2013 Published: September 17, 2013

doi:10.5296/ire.v1i1.4071ＵRL: http://dx.doi.org/10.5296/ire.v1i1.4071

\begin{abstract}
E-textbooks have experienced a lower than anticipated rate of adoption among college students. Studies consistently show a student preference for paper versus e-textbooks. When seeking an explanation for the continued reluctance of students to adopt e-textbooks, it is necessary to consider e-textbooks as a technological innovation. This is an exploratory study of the first year of a pilot program during which 991 students in 9 core courses in the Virginia State University (VSU) Reginald F. Lewis College of Business (RFLCB) replaced traditional textbooks with openly licensed e-textbooks. A questionnaire was administered to students who had participated in the e-textbook pilot study in the second semester of the implementation. The adoption process was examined using Venkatesh's Unified Theory of Acceptance and Use of Technology (UTAUT) as a framework. The questions in the survey were categorized to represent performance expectancy and effort expectancy; two of the four primary constructs in the UTAUT. In accordance with the UTAUT framework, the moderating variables, age, experience, gender and voluntariness, were cross-tabulated with
\end{abstract}


these constructs to see how the moderating factors might influence adoption of digital textbooks. Results show that student gender and voluntariness, as expressed as reported time spent with e-textbook, need to be taken into account when implementing technological innovations such as an e-textbook initiative.

Keywords: E-textbooks, diffusion of innovation, adoption, UTAUT, technology, retention, affordable textbooks, access, ICT

\section{Introduction}

In the fall of 2010 Virginia State University (VSU) and textbook publisher Flat World Knowledge (FWK) announced a groundbreaking textbook seat-license initiative that was designed to provide students at the Reginald F. Lewis College of Business (RFLCB) with increased access to their course materials at significantly lower costs. In the first two semesters of the pilot program students from 9 separate courses were introduced to Flat World Knowledge e-textbooks.

Students view textbooks as an important element of their courses and associate helpful textbooks with helpful classes (Besser et al., 1999). Faculty at RFLCB were concerned, based on an internal report as well as their own in class experience that a large number of students (almost $60 \%$ according to the internal report) were not purchasing textbooks. A primary reason cited by students for not purchasing textbooks was affordability. The RFLCB e-textbook initiative was designed to remove cost as an obstacle for students to access required course content. It was also designed to provide unlimited access to the e-textbook long after taking the course.

Early studies on electronic textbook adoption have been mixed at best. In a 2008 study, Shepperd et al. determined that the students using e-textbooks books and traditional textbooks for a course did not differ in grades. Although students reported that e-textbooks were easy to use "they appeared not to like it much, rated it as somewhat inconvenient, and seemed reluctant to recommend it to others" (Shepperd et al., 2008). While recommending that instructors exercise caution in adopting electronic textbooks the authors concede "electronic texts may increase in popularity once students become more familiar and comfortable with reading books on computers" (Shepperd et al., 2008).

To understand the adoption process we need to, first of all, have an understanding of expectations students have for electronic textbooks. Some of the potential advantages are reduced cost, environmentally friendly, the ability to conduct keyword searches and the incorporation of multimedia features. Disadvantages listed in previous studies include the need to have access to a computer, the need for an Internet connection, the inconvenience associated with bringing computer-based content to class, and restrictions on where to study (Sheppard et al., 2008). These perceived disadvantages are rapidly disappearing with the proliferation file formats that can be used with e-textbooks readers, net-books, tablet computers, and smart phones.

A 2012 report "Digital \& the New College Experience" commissioned by Google provides some interesting insights into the future of the textbook. For instance, the traditional 
bookstore is the source of choice for only $40 \%$ of students who are researching textbooks. Price is the largest consideration and $50 \%$ of students say they will "opt out" of purchasing a textbook if they deem it too expensive. The study also shows that only $50 \%$ of students at private colleges and $43 \%$ of those at public universities always purchase an assigned textbook. Of those opting out, $48 \%$ will claim the textbook is not necessary, $46 \%$ will attribute their decision to cost, and $26 \%$ will borrow or share a textbook with others. Our experience at the College of Business validates the data.

Due to their lower costs and easy accessibility, e-textbooks might seem to provide a logical alternative. In fact, this was one of the motivations for the move to e-textbooks at the time of the pilot study. Most students own or have access to devices that can deliver e-textbook content; $74 \%$ of college students own a smartphone and $42 \%$ own an e-reader, tablet, or iPad. Most students are also using digital content in classes already. The Google study also finds that $86 \%$ of college students are supplementing course content with digital content they discover on their own. $50 \%$ of college students have digitally shared study materials; primarily through email (77\%), texting (49\%), and social networks (44\%). 47\% digitally share with peers once a week or more.

Despite the costs of traditional textbooks and the increasingly online, digital lifestyle of college students, as of August 2013, only about 6\% of students are using a "core digital textbook" as their main course material (Book Industry Study Group, 2013). Yet, 61\% of students have never purchased an e-textbook. The main reason given in the Google survey is that students $(55 \%)$ prefer hard copy textbooks. We begin this study with the premise that e-textbooks constitute a significant departure from the traditional textbook in terms of function and delivery. As such, e-textbooks constitute an innovation rather that is substitutable, but not directly interchangeable, with a traditional textbook. It cannot, therefore, be expected that the experience using a traditional textbook will completely prepare a student to interact with an e-textbook. There is an inevitable learning curve associated with digital content delivery. This needs to be factored into an e-textbook initiative where students and faculty are expected to alter the way they have traditionally interacted with course content.

To understand the resistance to e-textbook adoption, it is necessary to look past the perception many hold that hard copy textbooks and e-textbooks are essentially the same. While both serve to deliver course content, they do so using different processes. It will be beneficial, therefore, to view e-textbooks as not just a substitution, but as an innovation as well. "An innovation is an idea, practice, or object that is perceived as new by an individual or other unit of adoption" (Rogers, 2003). The adoption of new innovations takes time (Rogers, 2003). It also takes an understanding of why and how the innovation is worth adopting at all. E-textbooks represent an innovation that involves the use of technology. There is a learning curve associated with this change. And, as with any innovation, its adoption is dependent upon proper communication, a perceived or real benefit, and a shift in the established paradigm.

Part of what makes e-textbooks an innovation is the use of ICT (information and communication technology) as the medium through which textbook content is delivered. 
Increasingly, ICT is being seen as "an inevitable precondition for the implementation of e-learning" (Loogma et al., 2011). Digital literacy and ICT are also a way to provide students with hands-on experience that will enhance their expertise working with technology and prepare them for future employment. Although students are becoming increasingly familiar with ICT in their daily lives, this does not necessarily translate to the classroom or their experiences with textbooks.

McNeish et al. (2012) conducted a study of students who were reluctant to give up hard copy textbooks. They found that students who were resistant to e-textbooks believed that hard copy textbooks facilitated their learning and study processes. They also felt hard copy textbooks were more permanent, that is "(1) it remains usable, (2) it is available for some period of time, and (3) it is under control of the holder of the document" (McNeish et al., 2012).

These attitudes are not surprising and support the assertion that e-textbooks and other forms of digital content represent an innovation that requires users to learn new skills and processes. Much of the debate over e-textbooks in academia places e-textbooks and hard copy textbooks in opposition to one another. In this light, it is reasonable for students and faculty alike, to choose the product they know and have become comfortable in using to one which is less familiar.

A 1992 Dillon article posits two schools of thought: those who believe "paper is far superior and will never be replaced by screens" and those who believe "electronic text will soon replace paper" (Dillon, 1992). The former argument focuses on the tactile qualities of paper as well as references to reading scenarios such as reading on the beach that in 1992, were not as plausible as they are today. The arguments for electronic text were "ease of storage and retrieval, flexibility of structure, and saving of natural resources" (Dillon, 1992). Dillon's review of the preceding 15 years of literature that compared paper text to electronic text found that most studies favored paper although he criticized the extant literature for focusing on outcomes over process.

A more recent article points to continued objective and subjective student reservations with electronic text and on-screen reading (Ackerman \& Goldsmith, 2011). Given that these attitudes still persist 20 years after the Dillon review, the authors "call into question the common assumption that as long as no new technological skills are explicitly required, learners can adapt seamlessly into computerized learning environments by applying skills proven to be effective on paper" (Ackerman \& Goldsmith, 2011).

The UTAUT (Unified Theory of Acceptance and Use of Technology) identifies four constructs as "direct determinants of user acceptance and usage behavior: performance expectancy, effort expectancy, social influence, and facilitating conditions" (Venkatesh et al., 2003). The UTAUT also specifies four moderating variables that have been shown to increase the predictive ability of this model. They are age, experience, gender, and voluntariness.

Effort expectancy is the "degree of ease associated with the use of the system" (Venkatesh et al., 2003). Studies show that effort expectancy has a significant influence on an individual's 
intention to adopt new technology (Wang, 2010; Shu \& Chuang, 2011). Performance expectancy is "the degree to which an individual believes the system will help him or her attain gains in job performance" (Venkatesh et al., 2003). In the context of e-textbooks, early studies show that many judge an e-textbook by determining how well it can mimic hard copy textbooks. Characteristics of performance expectancy include usefulness, relative advantage, and outcome expectations (Venkatesh et al., 2003). Studies also show performance expectancy to be strongly related to behavioral intention (Wang, 2010; Shu \& Chuang, 2011).

Social influence is "the degree to which an individual perceives that important others believe he or she should use the new system" (Venkatesh et al., 2003). This is moderated by age, gender, experience and voluntariness. It is stronger for women in mandatory settings and earlier stages of experience. While we did not specifically measure for social experience, some of the results suggest strategies that can be employed to incorporate this aspect.

Facilitating conditions is "the degree to which an individual believes that an organization and technical infrastructure exists to support the use of the system" (Venkatesh et al., 2003). It is moderated by age and experience and stronger for older workers with increasing experience. The primary facilitating condition for this initiative was the decision to provide the e-textbooks to students at no cost. This was, in fact, a primary condition under which the pilot study was conducted. The actual costs were covered by the university and by an external grant. It was a factor that was so intertwined with the project, the questionnaire failed to address the influence of this construct.

\section{Research Questions}

The UTAUT theory distinguishes between four main effects; effort expectancy, performance expectancy, social influence and facilitating conditions. This exploratory study focuses on effort expectancy and performance expectancy; both of which concentrate directly on the interaction between students and the e-textbook. In the case of effort expectancy students were asked questions relating to the amount of effort they needed to exert when using a traditional textbook as compared with an e-textbook. The performance expectancy construct addresses questions related to features and benefits of e-textbooks in contrast with traditional textbooks.

These constructs reflected the primary focus of the e-textbook initiative at this institution. As the first year of the pilot study ended, we wanted to know whether students found the e-textbooks easy to use, whether they found the features of the e-textbook useful, and how they felt the e-textbooks stacked up to traditional textbooks in effort and performance.

Another crucial element in the UTAUT relates four moderating variables to the main effects. Faculty had seen differences in how students related to e-textbooks; particularly with regard to gender. We wanted to further explore this by examining student responses to questions of performance and effort expectancy. We wanted to determine if differences in the moderating variables age, gender, experience, and voluntariness would provide an inside into the adoption process of e-textbooks. 
Therefore, this study examined e-textbook adoption at two levels. The first two questions were designed to look at overall attitudes of students to e-textbook use and features.

R1: Will there be an overall difference in the student attitudes toward performance expectancy as opposed to effort expectancy?

R2: Will student attitudes toward effort and performance expectancy be tempered when they are asked to make a direct comparison with traditional textbooks?

The remaining questions are at a more granular level and examine, in turn, the influence of each of the four moderating variables in the adoption process for e-textbooks.

R3: Does the moderating effects of age affect students' attitudes toward e-textbooks?

R4: Does the moderating effects of experience affect students' attitudes toward e-textbooks?

R5: Does the moderating effects of experience affect students' attitudes toward e-textbooks?

R6: Does the moderating effects of voluntariness affect students' attitudes toward e-textbooks?

\section{Methodology}

In this exploratory study, we will use the Unified Theory of Technological Acceptance and Use (UTAUT) (Venkatesh et al., 2003) to examine the process of e-textbook adoption. Student behaviors and reported attitudes from a year-long pilot program during which 991 students in 9 core courses at the Reginald F. Lewis College of Business at Virginia State University replaced traditional textbooks with openly licensed digital books. The study will highlight potential explanations for a slower-than-expected growth in e-textbook adoption.

Instructors teaching nine courses from the Reginald F. Lewis College of Business (RFLCB) Core Curriculum chose to adopt e-textbooks provided by Flat World Knowledge (FWK) in fall 2010 and spring 2011. The RFLCB developed a seat license program that provided students a consistent platform for delivery of their digital content regardless of the course or subject matter. The adoption was an important part of a larger plan to offer College of Business students affordable and accessible course content across the entire curriculum. The initial adoption was limited due to the limited number of offerings in the fledgling FWK catalog as well as the need for textbooks to be course-appropriate and meet with the approval of course instructors. A total of 507 undergraduate business majors registered 690 seat-licenses in the fall. In the spring 484 students registered 681 seat licenses.

This study will focus on a Qualtrics survey that was emailed to students who had registered a seat-license at the end of the spring semester. 139 of the 484 registered students completed the survey. $38 \%$ of the respondents to the Spring 2011 were male and $63 \%$ were female. Freshmen comprised $33 \%$ of the respondents, sophomores $24 \%$, juniors $25 \%$, and seniors $18 \%$. Approximately half of the students (49\%) who responded to the survey had had a 
course using a Flat World e-textbook during the fall 2010 semester as well as the spring 2011 semester. The other half were using Flat World e-textbooks for the first time (51\%).

A Qualtrics survey questionnaire was emailed to students at the end of the second semester of the pilot study. Students were asked about their study habits, their use of, and attitudes towards the e-textbooks using questions on a 5-point Likert scale. Although students were experiencing different e-textbooks they were all from the same publisher and had consistent features and processes for delivering content. For the purposes of this study, the questions were categorized to match the UTAUT constructs. Effort expectancy was represented by the statements; (1) The e-textbook was easy to use, (2) I could use the e-textbook to study in a variety of study environments, (3) the e-textbook was easy to read, and (4) I prefer the portability of the e-textbook over a traditional textbook.

Performance expectancy was represented by the statements; (1) Using the e-textbook helped me engage more with the course than a paper textbook, (2) I liked how the e-textbook linked to other resources, (3) I find the e-textbook more useful than traditional textbooks, and (4) the e-textbook provided more up-to-date material then the traditional textbook. Further, three of the eight questions (R4: effort expectancy; and R3 and R4: performance expectancy) asked students to compare their experience with e-textbooks to their experience with traditional paper textbooks.

The four moderating variables; age, experience, gender, and voluntariness were explored using a cross tabulation method. We compared the answers of male to female students. Effort expectancy is moderated by gender, age and experience and has been shown to be stronger for younger women in earlier stages of experience (Venkatesh et al., 2003). According to Venkatesh et al. (2003) gender and age are also primary moderators for performance expectancy. They hypothesize that men are more highly task oriented and that young workers place more emphasis on extrinsic rewards.

Based on this, we were expecting the cross tabulation to reveal some differences in both effort expectancy and performance expectancy due to age and gender. We used the self-reported gender information to distinguish gender. Age was represented by student classification; freshman through senior year. We designated the freshmen and sophomores in one category and the juniors and seniors in the other. Although this was not a perfect way to determine age, the University consists primarily of traditional students who will most likely have entered college directly after high school.

To represent the experience moderator, students were asked whether they had used an e-textbook in the fall 2010 semester or whether the spring 2011 semester was their first experience with e-textbooks. This variable has been shown to be a moderator for effort expectancy. We wanted to see if there were any significant differences between students who were using e-textbooks for the first time as compared to students who had a semester to become more familiar with e-textbooks.

We interpreted voluntariness on how much time students reported using their e-textbooks relative to traditional textbooks. We believe that students who reported using the e-textbook 
more than they used a traditional textbook probably found some aspects of the experience to be positive enough to elicit this behavior. We divided these students into those who used the e-textbook more than the traditional textbook, those who used it less, and those who reported using both mediums about the same amount of time. Voluntariness has been associated with social influence in the UTAUT model (Venkatesh et al., 2003).

\section{Results}

Analysis of the data suggest that the research questions provide insightful window into the students' perspective on e-textbooks and all that is involved with incorporating digital textbooks as part of their learning and adoption process.

R1: Will there be an overall difference in the student attitudes toward performance expectancy as opposed to effort expectancy?

The overall attitude of students toward e-textbooks was very positive. Figure 1 shows that students, regardless of gender, were in agreement with the statements in the survey. The most positive overall responses were statements that reflected effort expectancy. Almost $95 \%$ of the students strongly agreed or agreed that "Flat World Knowledge e-textbook was easy to use", and approximately 90\% agreed with the statements; "I could use the Flat World Knowledge e-textbook in a variety of study environments;" and, "the Flat World Knowledge e-textbook was easy to read."

The statements regarding performance expectancy, although positive, were less positively rated than effort expectancy statements. $78 \%$ of students agreed that "I liked how the Flat World Knowledge e-textbook linked to other resources." $78 \%$ of students also agreed that "the Flat World Knowledge e-textbook provided access to more up-to-date material than that available in my print textbooks."

R2: Will student attitudes toward effort and performance expectancy be tempered when they are asked to make a direct comparison with traditional textbooks?

The lowest level of positive responses came in response to the three statements that asked students to compare e-textbooks to traditional textbooks. Only $72 \%$ of students agreed with the statement "I prefer the portability of e-textbook over traditional textbooks." $68 \%$ agreed with the statement "I find Flat World Knowledge digital content more useful than traditional textbooks." Just over $60 \%$ of the students agreed that "using the Flat World Knowledge e-textbook helped me engage with the course more than a paper textbook." We also asked students to consider the statement "I prefer the e-textbooks to traditional textbooks." $67 \%$ of the students agreed or strongly agreed with this statement. We consider this to be more of an overall summary statement which will be discussed in conjunction with all the constructs in the UTAUT model. 


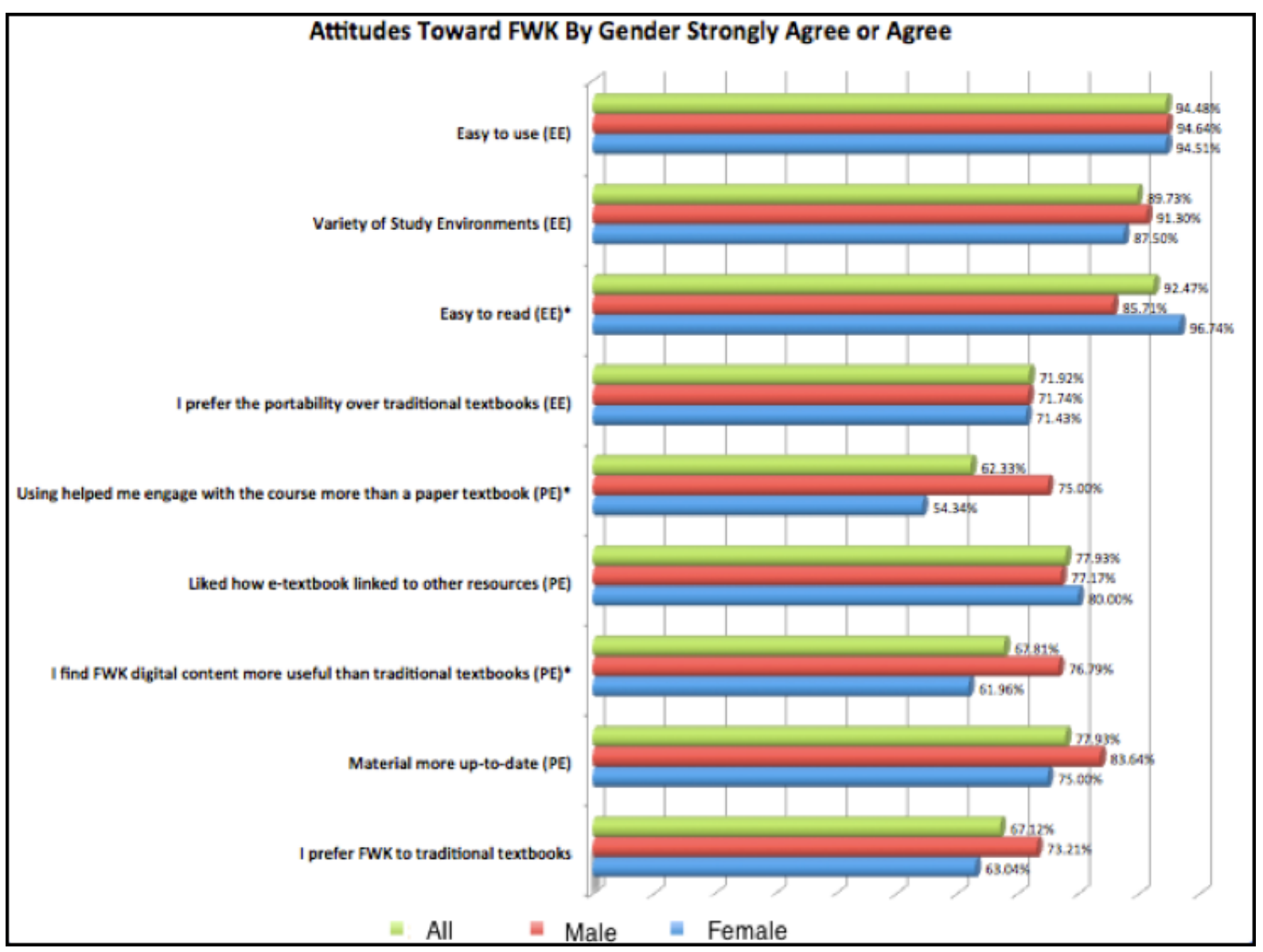

Figure 1. Student Likert scale results Overall and by Gender

R3: Does the moderating effects of age affect students' attitudes toward e-textbooks?

R4: Does the moderating effects of experience affect students' attitudes toward e-textbooks?

In this study, we looked at four variables that have been identified as moderators in the UTAUT model. Table 1 and Table 2 show the summary results of all the cross tabulations that were performed. To look at possible age effects, we divided the students into upper and lower class and examined their responses to the survey. Based on our representation of age, we found no significant effects in this variable (Table 2). Nor did we find any significant differences in our experience variable (Table 2). We had posited that students who had used the e-textbooks for two semesters might have had a difference in their attitudes toward the e-textbooks; but this was not supported by the data. 
Table 1. Moderator effects for Gender and Voluntariness

\begin{tabular}{|c|c|c|c|c|c|c|c|}
\hline \multirow[b]{2}{*}{$\begin{array}{l}\text { Percentages Represent } \\
\text { "Strongly Agree" \& } \\
\text { "Agree" Responses }\end{array}$} & \multicolumn{3}{|l|}{ Gender } & \multicolumn{4}{|c|}{ Read e-textbook (Voluntariness) } \\
\hline & Male & Female & $p$-value & $\begin{array}{c}\text { more } \\
\text { than a } \\
\text { paper } \\
\text { textbook }\end{array}$ & $\begin{array}{l}\text { same } \\
\text { amount } \\
\text { of time as } \\
\text { a paper } \\
\text { textbook }\end{array}$ & $\begin{array}{l}\text { less than a } \\
\text { paper } \\
\text { textbook }\end{array}$ & $p$-value \\
\hline \multicolumn{8}{|l|}{ Effort Expectancy } \\
\hline $\begin{array}{l}\text { E-textbook was easy to } \\
\text { use. }\end{array}$ & $94.64 \%$ & $94.51 \%$ & 0.66 & $\begin{array}{c}100.00 \% \\
(77)\end{array}$ & $\begin{array}{l}90.70 \% \\
(39)\end{array}$ & $\begin{array}{l}85.19 \% \\
(23)\end{array}$ & $0.01 *$ \\
\hline $\begin{array}{l}\text { I could use e-textbook } \\
\text { in a variety of study } \\
\text { environments. }\end{array}$ & $87.50 \%$ & $91.30 \%$ & 0.26 & $\begin{array}{c}96.10 \% \\
(74)\end{array}$ & $\begin{array}{l}90.91 \% \\
(40)\end{array}$ & $\begin{array}{l}70.37 \% \\
(19)\end{array}$ & $0.02 *$ \\
\hline $\begin{array}{l}\text { E-textbook was easy to } \\
\text { read. }\end{array}$ & $85.71 \%$ & $96.74 \%$ & $0.03 *$ & $\begin{array}{c}97.40 \% \\
(75)\end{array}$ & $\begin{array}{c}86.36 \% \\
(38)\end{array}$ & $\begin{array}{c}88.89 \% \\
(24)\end{array}$ & 0.14 \\
\hline $\begin{array}{l}\text { I prefer the portability } \\
\text { of e-textbooks to that of } \\
\text { traditional textbooks. }\end{array}$ & $71.43 \%$ & $71.74 \%$ & 0.93 & $\begin{array}{c}88.31 \% \\
(68)\end{array}$ & $\begin{array}{l}56.82 \% \\
(25)\end{array}$ & $\begin{array}{c}48.15 \% \\
(13)\end{array}$ & $0.00 *$ \\
\hline \multicolumn{8}{|l|}{ Performance Expectancy } \\
\hline $\begin{array}{l}\text { Using the e-textbook } \\
\text { helped me engage with } \\
\text { the course more than a } \\
\text { paper textbook. }\end{array}$ & $75.00 \%$ & $54.35 \%$ & $0.02 *$ & $\begin{array}{c}84.42 \% \\
(65)\end{array}$ & $\begin{array}{c}38.64 \% \\
(17)\end{array}$ & $\begin{array}{l}37.04 \% \\
(10)\end{array}$ & $0.00 *$ \\
\hline $\begin{array}{l}\text { I liked how the } \\
\text { e-textbook linked to } \\
\text { other resources. }\end{array}$ & $80.00 \%$ & $77.17 \%$ & 0.47 & $\begin{array}{c}88.31 \% \\
(68)\end{array}$ & $\begin{array}{c}68.18 \% \\
(30)\end{array}$ & $\begin{array}{l}65.38 \% \\
(17)\end{array}$ & $0.02 *$ \\
\hline $\begin{array}{l}\text { I find the e-textbook } \\
\text { more useful than } \\
\text { traditional textbooks. }\end{array}$ & $76.79 \%$ & $61.96 \%$ & $0.05^{*}$ & $\begin{array}{c}90.91 \% \\
(70)\end{array}$ & $\begin{array}{c}45.45 \% \\
(20)\end{array}$ & $\begin{array}{l}37.04 \% \\
(10)\end{array}$ & $0.00 *$ \\
\hline $\begin{array}{l}\text { The e-textbook } \\
\text { provided access to more } \\
\text { up-to-date material than } \\
\text { is available in my print } \\
\text { textbooks. }\end{array}$ & $83.64 \%$ & $75.00 \%$ & 0.45 & $\begin{array}{c}94.74 \% \\
(59)\end{array}$ & $\begin{array}{l}65.91 \% \\
(27)\end{array}$ & $\begin{array}{l}51.85 \% \\
(14)\end{array}$ & $0.00 *$ \\
\hline \multicolumn{8}{|l|}{ Summary Statement } \\
\hline $\begin{array}{l}\text { I prefer e-textbook } \\
\text { digital content to } \\
\text { traditional textbooks. }\end{array}$ & $73.21 \%$ & $63.04 \%$ & 0.53 & $\begin{array}{l}89.61 \% \\
(69)\end{array}$ & $\begin{array}{l}52.27 \% \\
(23)\end{array}$ & $25.93 \%(7)$ & $0.00 *$ \\
\hline
\end{tabular}


Table 2. Moderator effects for Age and Experience

\begin{tabular}{|c|c|c|c|c|c|c|}
\hline \multirow{2}{*}{$\begin{array}{c}\text { Percentages Represent } \\
\text { "Strongly Agree" \& "Agree" } \\
\text { Responses }\end{array}$} & \multicolumn{2}{|c|}{ Classification (Age) } & \multicolumn{4}{|c|}{$\begin{array}{l}\text { Used e-textbook last } \\
\text { semester (Experience) }\end{array}$} \\
\hline & $\begin{array}{l}\text { Freshmen, } \\
\text { Sophomore }\end{array}$ & $\begin{array}{l}\text { Junior, } \\
\text { Senior }\end{array}$ & p-value & yes & no & p-value \\
\hline \multicolumn{7}{|l|}{ Effort Expectancy } \\
\hline E-textbook was easy to use. & $94.05 \%$ & $95.08 \%$ & 0.51 & $93.06 \%$ & $95.89 \%$ & 0.44 \\
\hline $\begin{array}{l}\text { I could use e-textbook in a } \\
\text { variety of study environments. }\end{array}$ & $91.67 \%$ & $88.71 \%$ & 0.39 & $90.28 \%$ & $89.19 \%$ & 0.89 \\
\hline E-textbook was easy to read. & $91.67 \%$ & $93.55 \%$ & 0.84 & $93.06 \%$ & $91.89 \%$ & 0.69 \\
\hline $\begin{array}{l}\text { I prefer the portability of } \\
\text { e-textbooks to that of } \\
\text { traditional textbooks. }\end{array}$ & $67.86 \%$ & $77.42 \%$ & 0.53 & $75.00 \%$ & $68.92 \%$ & 0.69 \\
\hline \multicolumn{7}{|l|}{ Performance Expectancy } \\
\hline $\begin{array}{l}\text { Using the e-textbook helped } \\
\text { me engage with the course } \\
\text { more than a paper textbook. }\end{array}$ & $63.10 \%$ & $59.68 \%$ & 0.60 & $68.06 \%$ & $56.76 \%$ & 0.22 \\
\hline $\begin{array}{l}\text { I liked how the e-textbook } \\
\text { linked to other resources. }\end{array}$ & $79.76 \%$ & $77.05 \%$ & 0.53 & $80.56 \%$ & $75.34 \%$ & 0.46 \\
\hline $\begin{array}{l}\text { I find the e-textbook more } \\
\text { useful than traditional } \\
\text { textbooks. }\end{array}$ & $63.10 \%$ & $75.81 \%$ & 0.11 & $72.22 \%$ & $63.51 \%$ & 0.60 \\
\hline $\begin{array}{l}\text { The e-textbook provided } \\
\text { access to more up-to-date } \\
\text { material than is available in my } \\
\text { print textbooks. }\end{array}$ & $74.70 \%$ & $82.26 \%$ & 0.43 & $81.69 \%$ & $74.32 \%$ & 0.44 \\
\hline \multicolumn{7}{|l|}{ Summary Statement } \\
\hline $\begin{array}{l}\text { I prefer e-textbook digital } \\
\text { content to traditional } \\
\text { textbooks. }\end{array}$ & $65.48 \%$ & $69.35 \%$ & 0.74 & $73.61 \%$ & $60.81 \%$ & 0.20 \\
\hline
\end{tabular}

R5: Does the moderating effects of gender affect students' attitudes toward e-textbooks?

We did discover some significant effects in the area of gender and voluntariness (Table 1). When we examine students by gender, there is a significant difference between male and female students regarding how easy the e-textbook was to read. $97 \%$ of female students found the e-textbooks easy to read compared to $86 \%$ of the male students. There was also a significant difference in two statements in the performance expectancy construct. However, while female students were more in agreement with the effort expectancy item ("easy to use"), 
it was the male students who were more positive toward the performance expectancy items. When students were asked whether the e-textbook helped them to engage more with the course than a traditional textbook, there was a definite preference by male students $(75 \%)$ over female students (54\%). Male students also found the e-textbooks more "useful" by a margin of $77 \%$ to $62 \%$ for female students.

R6: Does the moderating effects of voluntariness affect students' attitudes toward e-textbooks?

We used the students' willingness to spend either more or less time with the e-textbooks as opposed to traditional textbooks as a proxy for voluntariness. There was a significant correlation between students who reported spending more time with their FWK e-textbook than they did with their hard copy textbooks (55\%) of the sample. In response to our summary statement, $90 \%$ of the students who reported spending more time with the e-textbooks ( $52 \%$ of our sample) preferred digital content over hard copy textbooks. $52 \%$ of the students who reported using e-textbooks and hard copy textbooks the same amount of time ( $28 \%$ of our sample) preferred the e-textbooks. Only $26 \%$ of the students who used the e-textbooks for less time than the traditional hard copy textbooks ( $20 \%$ of our sample) preferred the e-textbooks to the hard copy textbooks.

There was a significant effect for this variable in three of the four effort expectancy statements and in all four of the performance expectancy statements. All of the students $(100 \%)$ who reported using the Flat World e-textbooks more than the traditional textbooks deemed the e-textbooks "easy to use". Only $85 \%$ of students who reported using the e-textbooks less found them easy to use. $96 \%$ of students who reported using the e-textbooks more agreed they could "use the e-textbooks in a variety of study environments" while only $70 \%$ of the students who reported using digital textbooks less agreed with that statement. Even more dramatically, $88 \%$ of the students who reported reading the e-textbooks more than traditional textbooks "preferred the portability of digital content" as opposed to $48 \%$ of those who reported reading the e-textbooks less.

For the performance expectancy statements, there were also some noteworthy results. $90 \%$ of the students who read their e-textbooks more often reported them to be more useful than traditional textbooks, as opposed to only $37 \%$ of those who read the e-textbooks less. Similarly, $84 \%$ of the students who read e-textbooks more reported that e-textbooks helped them engage more with the course compared with only $37 \%$ of those who read the e-textbooks less than traditional textbooks.

\section{Discussion}

As we discuss the relationship between the constructs of the UTAUT and student attitudes and behaviors, it is important to point out the questionnaire was not specifically designed to isolate these constructs. This, in part, is the reason that the survey questions do not adequately address social influence or facilitating conditions. Thus, the focus of the questionnaire was on "ease of use" and "usefulness." We will, however, address UTAUT's other two main effects in our "Limitations and Recommendations". 
Our first two research questions focused on the entire student population. We discovered that few students had issues with the effort involved with using e-textbooks. They found that they could use the e-textbooks in a number of environments and that they were easy to read. They also appreciated some of the features exclusive to e-textbooks such as hyperlinks and the ability to quickly modify e-textbooks to keep them up to date. However, things became more contentious when students were asked to commit to a preference for e-textbooks over traditional textbooks.

Perhaps the least controversial comparison was portability. $71 \%$ of students found the e-textbooks more portable and yet, that means that almost $30 \%$ did not agree. Comments provided by students suggested that many felt that it was easier to carry a book than to carry a laptop or tablet containing the ePub file of the book. These students found an actual paper book to be more accessible than an e-textbook.

The other comparison questions were more emotionally charged. Students, as a group, were less likely to agree that e-textbooks were more engaging or useful than traditional textbooks. In retrospect, these were not particularly fair questions. The questions themselves were forcing students to claim a preference for one product over the other. This approach was similar to much of the earlier research and is flawed for the same reason. The issue at hand is not whether e-textbooks are better or more useful than traditional textbooks. The real issue is whether the digital delivery of course content is an effective way to provide students with necessary course resources.

Research questions 3-6 bring us a bit closer to understanding why adoption of e-textbook technology is not as uniform as we might have expected. R3 and R4 look at age and experience as factors moderating effort expectancy and performance expectancy. It turned out that there were no significant differences in the responses of upper class and underclass students. There was also no significant difference between students who were using the e-textbooks for the first time in the second semester of the pilot and those who had used it in the previous semester. Although the UTAUT suggests these as moderating factors, we might not have enough contrast, in the context of this study, between the age of students or time of experience to see the effects of these variables.

R5 and R6, on the other hand, provide us with an awareness of factors that can certainly lead to some actionable strategies in promoting e-textbook adoption among students. R5 addresses the issue of gender and this study points to a higher acceptance by male students for the e-textbook technology. Male students are more likely to find e-textbooks easy to read than are female students. A more dramatic indication of male preference comes in response to two of the statements we consider more controversial. Male students are significantly more likely to say that e-textbooks are more useful than traditional textbooks and that e-textbooks help them engage with the course more than traditional textbooks.

It is very clear from these findings that the gender differences need to be addressed. If our male students are more accepting of e-textbooks we will need to determine what strategies need to be employed with our female students. Perhaps the issue is with the delivery platform. 
Then again, we might need to spend more time showing students the relative advantages of the e-textbooks as opposed to placing them in opposition to the traditional textbooks.

The most dramatic differences were found with the moderating factor voluntariness. This is the type of finding that, in retrospect, seems to be the most obvious. We operationalized voluntariness as the amount of time a student reported spending with their e-textbook each week as opposed to a traditional textbook. Here the question of utility ("I found the e-textbook more useful than a traditional textbook") became much more polarized. $91 \%$ of the students who reported using e-textbooks more than traditional textbooks $(70 \%$ of respondents) found the e-textbooks more useful. Only $43 \%$ of the students who reported using the e-textbooks the same amount or less than a traditional textbook $(30 \%$ of the respondents) found the e-textbook more useful.

To turn this into useful information, we need to ask why students are using the e-textbooks less than traditional textbooks. One possible explanation is that instructors are less familiar with the delivery system for e-textbooks and are not comfortable explaining the differences to students. It is also possible that we are not adequately communicating to, either students or faculty, that this is a new technology and that we must acknowledge that there is a learning curve that needs to be addressed with the adoption of e-textbooks.

\section{Limitations and Recommendations}

The questionnaire used in this study limited our scope to effort and performance expectancy. However, understanding the adoption of e-textbooks, especially under the conditions of our pilot study, requires us to extend the scope to include facilitating conditions. The cost of textbooks and the inability of many students to afford them was a primary motivation for this initiative. We knew we could offer students digital content to replace traditional textbooks at little or no cost. This was our primary facilitating condition. The Google study cited in the introduction reinforces the purpose of the e-textbook initiative; which was to provide students access to more affordable resources and to long-term use of knowledge. To that end, the pilot program was designed so that students would not have to pay for their e-textbooks and would have access to the content long after taking the course. An infrastructure was also created to facilitate student registration to the Flat World Knowledge website. In addition, students were given the option of downloading their e-textbook files in various formats so that they might read their e-textbooks without Internet access.

Although access and affordability were a major component of the e-textbook adoption, the survey neglected to ask students about the impact of free e-textbooks. While we can certainly be encouraged that $67 \%$ of the students preferred the e-textbooks over traditional textbooks, the fact that students did not have to pay for the e-textbooks certainly contributed to that percentage. Student comments bring that aspect into high relief. It is evident that, for many, this particular facilitating factor outweighs many other considerations. A junior male student wrote, "You don't have to carry a digital book, and it's free; most times, books are expensive". A sophomore male student shared, "When I came here and they told me you don't have to pay for your textbook because it's online, I was like -YES! Awesome!”. 
Other comments make it clear that the "free" aspect outweighs other considerations. Another junior male states, "With hard copy books, it's good to have the text right in front of you, because you can flip through the pages. Sometimes using it electronically, it's a problem because you can't scroll down the pages like you want to, and sometimes you have trouble with the technology, that's why I prefer hard copy. But it's free, so I don't mind that problem." This begs the question, "How will students attitudes change toward e-textbooks when there is a monetary cost to the students?"

This brings us back to the UTAUT and makes this model an essential aspect in the formation of strategies to promote e-textbook usage. Our goal in adopting the e-textbook initiative is to provide access to course content for students who are unwilling or unable to pay for traditional textbooks and to ensure that this information is available to them throughout their entire career. It has been shown, at our College of Business, that the introduction of e-textbooks into core business courses has increased retention and improved student grades (Feldstein et al., 2012). This makes for a compelling argument, but the UTAUT model highlights other factors that need to be considered as we transition to e-textbooks.

This study has shown that gender plays a role in student attitudes towards e-textbooks. Although female students find the e-textbooks easy to read, they are less likely to find them more engaging than are their male counterparts. They are also less likely to find them more useful than male students. This needs to be a consideration in a strategic approach to the successful adoption of e-textbooks. Further research is in order to identify whether aspects of the delivery of e-textbooks and digital content need to be improved or whether a different type of support system needs to be implemented.

The most powerful finding in this study might also seem to be the most obvious. Students who reported using e-textbooks more than traditional textbooks were dramatically more positive about all aspects of effort and performance expectancy than were students who reported reading the e-textbooks less or the same amount of time as hard copy textbooks. There is more than one possible interpretation of this and that warrants further study. One interpretation would indicate that students, who might not have purchased the textbook otherwise, are finding the e-textbook to be valuable. This interpretation would be in line with the motivation for the e-textbook program.

Another interpretation would be that, as some student comments have indicated, the free aspect has changed student perceptions of the overall value. Yet, another possibility is that students truly find the benefits and features compelling and this has motivated them to spend more time with course content. These are all questions for future study as the use of e-textbooks becomes more prevalent. For now, it is important to approach the adoption of e-textbooks with an understanding that the technology through which digital content is delivered must be considered in any adoption strategy. Differences in student gender and differences in levels of motivation, as represented through voluntariness, must be considered.

It is also necessary to focus on all four constructs in the UTAUT model. In this study, despite the obvious influence of the facilitating conditions, statements about effort expectancy and performance expectancy were the focus of the student survey. This study also neglected the 
social influence construct. This must also be considered in any strategy and had an effect, as yet unmeasured, on the pilot study at this College. The following student comment illustrates this quite well; "It's benefited me through most of my classes, by not having to pay for my textbooks; it means they honestly care about our education. I believe it says great things about the College of Business".

\section{References}

Ackerman, R., \& Goldsmith, M. (2011). Metacognitive regulation of text learning: On screen versus on paper. Journal of Experimental Psychology: Applied, 17(1), 18-32. http://dx.doi.org/10.1037/a0022086

Besser, D., Stone, G., \& Nan, L. (1999). Textbooks and teaching: A lesson from students. Journalism \& Mass Communication Educator, 53(4), 4-17. http://dx.doi.org/10.1177/107769589805300401

Book Industry Study Group. (2013). Student Attitudes Toward Content in Higher Education. Retrieved from http://www.bisg.org/publications/product.php? $\mathrm{p}=22$

Dillon, A. (1992). Reading from paper versus screens: A critical review of the empirical literature. Ergonomics, 35, 1297-1326. http://dx.doi.org/10.1080/00140139208967394

Feldstein, A., Martin, M., Hudson, A., Warren, K., Hilton III, J., \& Wiley, D. (2012). Open Textbooks and Increased Student Access and Outcomes. European Journal of Open, Distance and E-Learning, 1-9.

Google, TNS, \& True. (2012). Digital \& the New College Experience (p. 30). Retrieved from http://ssl.gstatic.com/think/docs/digital-and-the-new-college-experience_research-studies.pdf

Loogma, K., Kruusvall, J., \& Ümarik, M. (2012). E-learning as innovation: Exploring innovativeness of the VET teachers' community in Estonia. Computers \& Education, 58, 808-817. http://dx.doi.org/10.1016/j.compedu.2011.10.005

McNeish, J., Foster, M., Francescucci, A., \& West, B. (2012). The Surprising Foil to Online Education: Students Won't Give Up Paper Textbooks. Journal for Advancement of Marketing Education, 20(3), 58-69.

Noyes, J. M., \& Garland, K. J. (2008). Computer- vs. paper-based tasks: are they equivalent? Ergonomics, 51(9), 1352-75. http://dx.doi.org/10.1080/00140130802170387

Rogers, E. M. (2003). Diffusion of Innovations (5th ed.). New York, NY: Free Press.

Shepperd, J., Grace, J., \& Koch, E. (2008). Evaluating the Electronic Textbook: Is It Time to Dispense With the Paper Text? Teaching of Psychology, 35(1), 2-5. http://dx.doi.org/10.1080/00986280701818532

Shu, W., \& Chuang, Y. (2011). The behavior of wiki users. Social Behavior and Personality, 39(300), 851-864. http://dx.doi.org/10.2224/sbp.2011.39.6.851 


\section{Macrothink}

International Research in Education

ISSN 2327-5499 2013, Vol. 1, No. 1

Wang, H., \& Wang, S. (2010). User Acceptance of Mobile Internet Based on the Unified Theory of Acceptance And Use of Technology: Investigating the Determinants and Gender Differences. Social Behavior and Personality an International Journal, 38(707), 415-426. http://dx.doi.org/10.2224/sbp.2010.38.3.415

Venkatesh, V., Morris, M., Davis, G., \& Davis, F. (2003). User acceptance of information technology: toward a unified view. MIS quarterly, 27(3), 425-478. Retrieved from http://www.jstor.org/stable/10.2307/30036540

\section{Copyright Disclaimer}

Copyright reserved by the authors.

This article is an open-access article distributed under the terms and conditions of the Creative Commons Attribution license (http://creativecommons.org/licenses/by/3.0/). 